(c) American Dairy Science Association, 2003.

\title{
Effects of Exogenous Glucagon on Lipids in Lipoproteins and Liver of Lactating Dairy Cows ${ }^{1}$
}

\author{
G. Bobe, B. N. Ametaj, J. W. Young, and D. C. Beitz \\ Nutritional Physiology Group, \\ Department of Animal Science, \\ lowa State University, Ames 50011-3150
}

\section{ABSTRACT}

Decreased concentrations of phospholipids, free cholesterol, and cholesteryl ester in plasma and liver are associated with fatty liver, a major metabolic disease of dairy cows in early lactation. The objective was to test whether daily subcutaneous injections of 7.5 and $15 \mathrm{mg}$ of glucagon, which can decrease concentrations of liver triacylglycerol, affect concentrations of plasma lipoprotein components and liver lipids other than triacylglycerol. Multiparous Holstein cows $(\mathrm{n}=32)$ were grouped on the basis of liver triacylglycerol concentrations at $\mathrm{d} 8$ postpartum into "normal" $(\mathrm{n}=8$; triacylglycerol $<1 \%$ liver wet wt) and "susceptible to fatty liver" (n $=24$; triacylglycerol $>1 \%$ liver wet wt) cows. Susceptible cows were assigned randomly to three groups and beginning at $\mathrm{d} 8$ postpartum received 0 (same for Normal cows), 2.5 , or $5 \mathrm{mg}$ of glucagon by subcutaneous injections every $8 \mathrm{~h}$ for $14 \mathrm{~d}$. In comparison to saline injections, subcutaneous injections of glucagon either increased or tended to increase concentrations of phospholipids and free cholesterol in liver, with greater increases of the latter during ambient temperatures below $35^{\circ} \mathrm{C}$. Glucagon injections decreased or tended to decrease concentrations of very low-density lipoproteintriacylglycerol, high-density lipoprotein $_{1}$-phospholipids, and high-density lipoprotein ${ }_{2}$-free cholesterol in plasma, with no changes of the latter two during ambient temperatures below $35^{\circ} \mathrm{C}$. The results indicate that subcutaneously administered glucagon has only minor effects on the lipid transport in plasma of dairy cows in early lactation with more beneficial effects occurring during ambient temperatures below $35^{\circ} \mathrm{C}$ and, most importantly, no indications that glucagon has negative effects.

Received February 19, 2003

Accepted April 22, 2003.

Corresponding author: D. C. Beitz; e-mail: dcbeitz@iastate.edu.

${ }^{1}$ Publication of the Iowa Agriculture and Home Economics Experiment Station, Ames; Project Number 3801.

(Key words: dairy cow, fatty liver, glucagon, lipoprotein)

Abbreviation key: HDL = high-density lipoprotein, $\mathbf{L D L}=$ low-density lipoprotein, $\mathbf{T A G}=$ triacylglycerol, VLDL = very low-density lipoprotein.

\section{INTRODUCTION}

Fatty liver (i.e., hepatic lipidosis) is a major metabolic disease that affects up to $50 \%$ of dairy cows in early lactation (Jorritsma et al., 2001). Fatty liver develops when hepatic uptake of NEFA exceeds hepatic secretion of lipids, which is caused partly by the slow rate at which ruminant liver assembles or secretes lipids (Bauchart, 1993; Gruffat et al., 1996; Graulet et al., 1998). Because of inadequate secretion in lipoproteins, many liver NEFA are converted to triacylglycerol (TAG) that are stored in the liver. High concentrations of liver TAG promote the synthesis of additional TAG and decrease the oxidation of NEFA (Grum et al., 1996), thereby further increasing accumulation of TAG in liver. Lower concentrations of phospholipids, free cholesterol, and cholesteryl ester in fatty liver (Saarinen and Shaw, 1950; Fronk et al., 1980; Herdt et al., 1983) indicate decreased hepatic synthesis of phospholipids, free cholesterol, and cholesteryl ester in fatty liver.

Lower concentrations of lipoprotein TAG, phospholipids, free cholesterol, cholesteryl ester, and total protein in plasma of cows with fatty liver (Herdt et al., 1983; Rayssiguier et al., 1988; Mazur et al., 1989; Bobowiec et al., 1997; Nakagawa et al., 1997) indicate decreased lipid transport in plasma and decreased hepatic assembly and secretion of lipoproteins. Decreased concentrations of steroidogenic compounds in plasma, such as free cholesterol and cholesteryl ester, could explain partly (Herdt, 1991; Katoh, 2002) why cows with fatty liver have decreased and delayed synthesis of steroidogenic hormones (Reid, 1984; Watson and Williams, 1987; Ropstad et al., 1989; Zhou et al., 1997) and decreased reproductive performance (Reid, 1983; Wensing et al., 1997).

In companion reports, it has been demonstrated that subcutaneous injections of glucagon at $15 \mathrm{mg} / \mathrm{d}$ for 14 
$\mathrm{d}$ beginning at $\mathrm{d} 8$ postpartum decreased concentrations of liver TAG in multiparous cows older than 3.5 yr (Bobe et al., 2003) and had beneficial effects on health and reproductive performance (Bobe, 2002). In monogastric species, glucagon decreases concentrations of plasma lipoprotein components because glucagon shifts the use of NEFA in hepatocytes from synthesis of TAG and other lipids to oxidation and ketogenesis of NEFA (McGarry and Foster, 1980; Witters and Trasko, 1979). In ruminants, the effect of glucagon on concentrations of plasma lipoprotein components and liver lipids has not been investigated.

The objective, therefore, was to determine whether subcutaneous injections of 7.5 and $15 \mathrm{mg} / \mathrm{d}$ of glucagon for $14 \mathrm{~d}$ starting at $\mathrm{d} 8$ postpartum affect lipid transport in plasma and concentrations of liver lipids of cows with elevated concentrations of liver TAG. More specifically, the objective was to determine the effects of 7.5 and $15 \mathrm{mg} / \mathrm{d}$ of glucagon on 1) concentrations of very lowdensity lipoprotein (VLDL)-, low-density lipoprotein (LDL)-, high-density lipoprotein, (density 1.063 to $1.125 \mathrm{~g} / \mathrm{ml} ; \mathrm{HDL}_{1}$ )-, and high-density lipoprotein ${ }_{2}$ (density 1.125 to $1.21 \mathrm{~g} / \mathrm{ml} ; \mathbf{H D L}_{2}$ )-TAG, phospholipids, free cholesterol, cholesteryl ester, and total protein in plasma and 2) concentrations of phospholipids, free cholesterol, and cholesteryl ester in liver.

\section{MATERIALS AND METHODS}

\section{Experimental Design}

During their final 4 wk prepartum, 32 multiparous Holstein cows were housed in a straw-bedded free-stall barn as a group. The number of cows housed together varied depending on the number of cows at that stage of gestation. The group was offered a typical NRC-recommended transition dry-cow TMR at $12.8 \mathrm{~kg} / \mathrm{cow}$ daily. The ration primarily consisted of corn, cottonseeds, and grass and alfalfa hay and had $1.50 \mathrm{Mcal} / \mathrm{kg}$ $\mathrm{NE}_{\mathrm{L}}, 15.1 \% \mathrm{CP}, 23.8 \% \mathrm{ADF}$, and $40.3 \% \mathrm{NDF}$. Additional grass hay was available ad libitum. Each cow was offered individually, in addition to the TMR and hay, $6 \mathrm{~kg}$ of cracked corn. All cows were visually healthy before parturition. After parturition, cows were housed in a tie-stall barn and offered twice daily a TMR that consisted primarily of corn, alfalfa hay, cottonseed, and soybean meal and had $1.72 \mathrm{Mcal} / \mathrm{kg} \mathrm{NE}, 16.8 \% \mathrm{CP}$, $16.5 \% \mathrm{ADF}$, and $29.1 \% \mathrm{NDF}$. All cows were managed and treated in accordance with guidelines established by the Iowa State University Committee on Animal Care.

At d 8 postpartum, cows were divided into two groups. Cows $(n=8)$ with liver TAG concentrations of $<1 \%$ of liver wet wt (saline normal) were injected subcutaneously with $60 \mathrm{ml}$ of $0.15 \mathrm{M} \mathrm{NaCl}$ every $8 \mathrm{~h}$ (0600, 1400, and $2200 \mathrm{~h}$ ) for $14 \mathrm{~d}$ starting at 1400 of d 8 postpartum. Cows ( $\mathrm{n}=24$; eight cows randomly assigned to each treatment group) with liver TAG concentrations of $>1 \%$ of liver wet wt (susceptible to fatty liver) were injected in a similar way three times daily with 0 (saline susceptible), $2.5(7.5 \mathrm{mg} / \mathrm{d})$, or $5(15 \mathrm{mg} / \mathrm{d}) \mathrm{mg}$ of lyophilized glucagon, every $8 \mathrm{~h}$ for $14 \mathrm{~d}$ starting on $\mathrm{d} 8$ postpartum. Further details of the experimental design, as well as several of the experimental techniques and methods, have been described in detail elsewhere (Bobe et al., 2003).

\section{Sampling and Analyses}

Liver. Liver samples were obtained by puncture biopsies at d $-4,3,8,11,15,22,28,36$, and 43 postpartum. An intensive series of liver biopsies was chosen to characterize the temporal changes of liver lipid concentrations during the development and treatment of fatty liver. The intensive sampling additionally provides information about the minimal length of an effective injection period required to decrease liver TAG. Methods of liver biopsy and lipid separation have been described in detail elsewhere (Bobe et al., 2003). A previous study involving an intensive series of liver biopsies, similar to the current study, demonstrated no effect on milk production and only very short-term negative effects on feed intake (Smith et al., 1997). In the current study, elevated body temperature above $39.5^{\circ} \mathrm{C}$ or swelling at the biopsy site was observed after less than 5\% of all liver biopsies. Biochemical parameters of stress, such as cortisol concentrations, however, were not measured.

For determination of composition of liver lipids, dried lipids were dissolved in $5 \mathrm{ml}$ of $1 \%$ Triton X-100 (Fisher Scientific, Fair Lawn, NJ) in $0.15 \mathrm{M} \mathrm{NaCl}$ at $37^{\circ} \mathrm{C}$. Concentrations of liver TAG (TAG kit number T7532; Pointe Scientific, Lincoln Park, MI), choline-containing phospholipids (phospholipids B kit number 990-54009; WAKO, Richmond, VA), total cholesterol (cholesterol kit number C7510; Pointe Scientific), and free cholesterol (free cholesterol C kit number 274-47109; WAKO) were determined for each liver lipid sample in triplicate on a microplate spectrophotometer (SPECTRAmax PLUS, Sunnyvale, CA). Concentrations of cholesteryl ester were calculated as the difference between concentrations of total and free cholesterol.

Lipoproteins. Before liver biopsies, blood samples were collected from the jugular vein at $\mathrm{d}-4,3,8$ (before first injection), 11, 15, 22 (during the injection period), 28,36 , and 43 (after last injection) postpartum. Blood was collected into 10-ml Vacutainer tubes (Beckton Dickinson and Co., Rutherford, NJ) containing $\mathrm{K}_{2^{-}}$ EDTA. Plasma was prepared by centrifugation within 20 min after sample collection. Lipoproteins were sepa- 
rated by ultracentrifugation in a discontinuous density gradient (Havel et al., 1955) with a L8-55M preparative ultracentrifuge and a type 50.2 TI rotor (Beckman Instruments, Inc., Palo Alto, CA). Plasma (18 ml) was overlaid with $5 \mathrm{ml}$ of $0.15 \mathrm{M} \mathrm{NaCl}$ (density =1.005) and centrifuged at $18^{\circ} \mathrm{C}$ for $18 \mathrm{~h}$ at $138,000 \times g$ before the top layer $(9 \mathrm{ml})$ was removed as chylomicrons and VLDL (density $<1.006 \mathrm{~g} / \mathrm{ml}$ ). The bottom layer $(14 \mathrm{ml})$ was mixed with $7.2 \mathrm{ml}$ of a solution (density $=1.177$ ) containing $1.33 \mathrm{M} \mathrm{NaCl}$ and $1.50 \mathrm{M} \mathrm{KBr}$.

The resulting mixture was overlaid with $1.8 \mathrm{ml}$ of a solution (density $=1.063$ ) containing $0.57 \mathrm{M} \mathrm{NaCl}$ and $0.51 \mathrm{M} \mathrm{KBr}$ and centrifuged at $18^{\circ} \mathrm{C}$ for $22 \mathrm{~h}$ at 138,000 $\times g$ before the top layer $(9 \mathrm{ml})$ was removed as LDL (density 1.006 to $1.063 \mathrm{~g} / \mathrm{ml}$ ). The bottom layer $(14 \mathrm{ml}$ ) then was mixed with $10.8 \mathrm{ml}$ of a solution (density = 1.187) containing $1.47 \mathrm{M} \mathrm{NaCl}$ and $1.59 \mathrm{M} \mathrm{KBr}$. The resulting mixture then was overlaid with $1.8 \mathrm{ml}$ of a solution (density = 1.125) containing $1.02 \mathrm{M} \mathrm{NaCl}$ and $1.05 \mathrm{M} \mathrm{KBr}$ and centrifuged at $18^{\circ} \mathrm{C}$ for $22 \mathrm{~h}$ at 138,000 $\times g$ before the top layer $(12.6 \mathrm{ml})$ was removed as $\mathrm{HDL}_{1}$ (density 1.063 to $1.125 \mathrm{~g} / \mathrm{ml}$ ). The bottom layer (14 ml) then was mixed with $10.8 \mathrm{ml}$ of a solution (density = 1.305) containing $2.32 \mathrm{M} \mathrm{NaCl}$ and $2.62 \mathrm{M} \mathrm{KBr}$. The resulting mixture then was overlaid with $1.8 \mathrm{ml}$ of a solution (density = 1.21) containing $1.63 \mathrm{M} \mathrm{NaCl}$ and $1.79 \mathrm{M} \mathrm{KBr}$ and centrifuged at $18^{\circ} \mathrm{C}$ for $22 \mathrm{~h}$ at 138,000 $\times g$ before the top layer $(12.6 \mathrm{ml})$ was removed as $\mathrm{HDL}_{2}$ (density 1.125 to $1.21 \mathrm{~g} / \mathrm{ml}$ ).

Lipoproteins were stored at $-20^{\circ} \mathrm{C}$ until analyzed. Concentrations of VLDL-, LDL-, HDL-, and VHDLTAG, -choline-containing phospholipids, -total cholesterol, and -free cholesterol were determined as described already for liver samples. Additionally, concentrations of VLDL-, LDL-, HDL-, and VHDL-total protein (total protein kit number T7528; Pointe Scientific) were determined. Concentrations of $\mathrm{HDL}_{2}$-TAG and VLDL-phospholipids, -total cholesterol, -free cholesterol, and -protein were below detection limits for most of the samples and, therefore, cannot be reported.

\section{Statistical Analysis}

Data were analyzed as a completely randomized repeated measures study using the mixed models procedures of SAS Version 8.2 (2001). The response variable was the change from the concentration at $d 8$ postpartum (the last time point before glucagon injections started) to the concentration at $d 11,15$, and 22 postpartum (which was d 3, 7, and 14 of injection period, respectively). The fixed effects were concentration of the response variable at $\mathrm{d} 8$ postpartum (as a linear covariate), treatment (saline normal, saline susceptible, 7.5 or $15 \mathrm{mg} / \mathrm{d}$ ), day of injection (d 11, 15, or 22 postpartum), ambient temperature $\left(<35\right.$ or $\left.>35^{\circ} \mathrm{C}\right)$, age of cow $(<3.5$ or $>3.5 \mathrm{yr}$ ), treatment $\times$ day of injection interaction, treatment $\times$ ambient temperature interaction, and treatment $\times$ age of cow interaction. A completely unrestricted variance-covariance structure was used to account for repeated measures taken on individual cows across time (d 11, 15, and 22 postpartum).

The original experimental design did not include age of cows and ambient temperature as fixed effects. During the experiment, it became apparent, however, that there were major differences in responses to subcutaneous injections of glucagon, which were associated with age of cows and ambient temperatures. Data of individual cows were categorized into ambient temperature below or above $35^{\circ} \mathrm{C}$ based on the peak temperatures for the majority of days of the injection period. There was a period of $50 \mathrm{~d}$ when peak ambient temperatures were between 35 and $40^{\circ} \mathrm{C}$ nearly every day, which decreased feed intake, milk production, and concentrations of lipoprotein components. Therefore, ambient temperature and age of cows and their interactions with glucagon treatment were included as fixed effects in the final model (Bobe et al., 2003).

The effects of 7.5 or $15 \mathrm{mg} / \mathrm{d}$ of glucagon were evaluated by comparing their estimated means averaged across $d 11,15$, and 22 postpartum with the corresponding estimated mean of the saline susceptible group using Student's $t$-test in the ESTIMATE statement. Interactions between glucagon and ambient temperature were evaluated by comparing the difference of estimated means averaged across $d 11,15$, and 22 postpartum between glucagon- and saline-treated groups during normal and elevated ambient temperatures using Student's $t$-test in the ESTIMATE statement. To obtain the correct degrees of freedom, the KENWARDROGER option was invoked. The KENWARDROGER option consists of the Satterthwaite adjustment for degrees of freedom with a Kenward-Roger adjustment on standard errors, which can be used for repeated measures studies (Douglass, 2002; Tempelman, 2002).

The effects of elevated concentrations of liver TAG (susceptible) on response variables were evaluated by using analysis of variance. The dependent variable was the concentration of each response variable at $d 8$ postpartum. The independent variables were the fixed effects of treatment (saline normal, saline susceptible, 7.5 or $15 \mathrm{mg} / \mathrm{d})$, ambient temperature $\left(<35\right.$ or $\left.>35^{\circ} \mathrm{C}\right)$, age of cow $(<3.5$ or $>3.5 \mathrm{yr})$, treatment $\times$ ambient temperature interaction, and treatment $\times$ age of cow interaction. The estimated mean of the saline normal group was compared with the estimated combined mean of the susceptible groups using a Student's $t$-test in the ESTIMATE statement. Means and SEM presented in figures are raw means and SEM. Significance was de- 


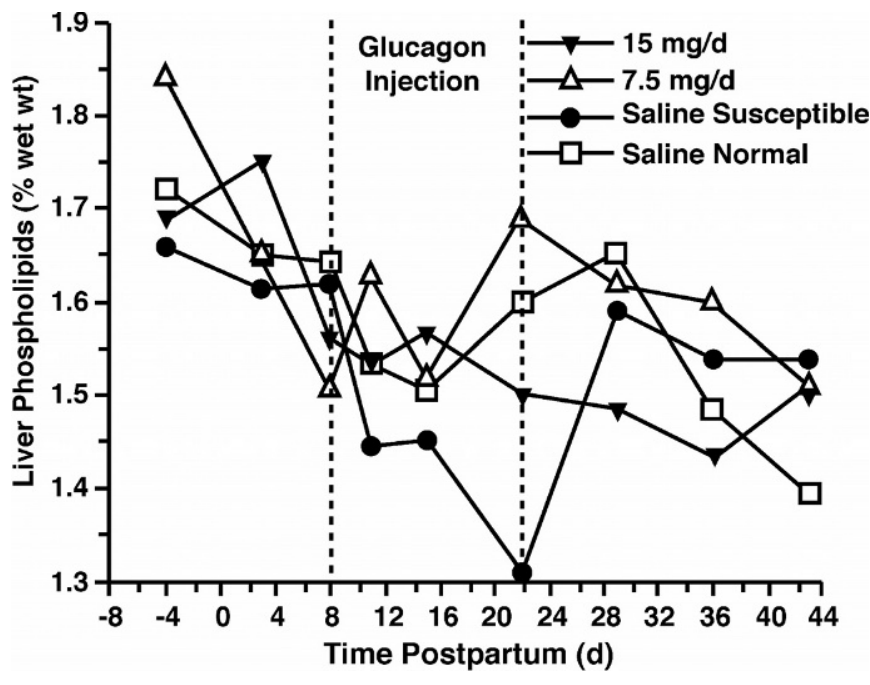

Figure 1. Effects of $7.5(P \leq 0.01)$ and $15 \mathrm{mg} / \mathrm{d}$ of glucagon $(P \leq$ 0.05 ) and of elevated liver triacylglycerol concentrations (Susceptible; $\mathrm{NS}$ ) on concentrations of liver phospholipids ( $\mathrm{SEM}=0.3$ to $2.1 ; \mathrm{n}=$ 8 in each treatment group).

clared at $P \leq 0.05$, and trends toward significance were declared at $P \leq 0.10$.

\section{RESULTS}

Subcutaneous injections of 7.5 and $15 \mathrm{mg} / \mathrm{d}$ of glucagon and elevated concentrations of liver TAG affected both concentrations of liver lipids and plasma lipoprotein components (Figures 1 to 12). In comparison to those for saline injections, concentrations of liver phospholipids remained higher during injections of 7.5 and $15 \mathrm{mg} / \mathrm{d}$ of glucagon in "susceptible" cows $(P \leq 0.01$ and $P \leq 0.05$, respectively; Figure 1). Injections of 7.5 and $15 \mathrm{mg} / \mathrm{d}$ of glucagon tended to increase concentrations of liver free cholesterol (both $P \leq 0.10$; Figure 2). The increase of liver free cholesterol was significant only during normal ambient temperatures $(P \leq 0.01$ versus $P>0.10$ during elevated ambient temperatures; Figure 3 ).

Among liver lipoprotein components, glucagon increased concentrations of $\mathrm{HDL}_{1}$-phospholipids less than did saline injections in "Susceptible" cows $(P \leq$ 0.01 for both dosages combined; Figure 4). The lack of increase of $\mathrm{HDL}_{1}$-phospholipids was limited to elevated ambient temperatures above $35^{\circ} \mathrm{C}(P \leq 0.10$ vs. $P>0.10$ during normal ambient temperatures below $35^{\circ} \mathrm{C}$; $\mathrm{n}=$ 7 to 9 in each treatment group; Figure 5). When both dosages were combined, glucagon tended to decrease concentrations of VLDL-TAG (Figure 6) and $\mathrm{HDL}_{2}$-free cholesterol (Figure 7). The decrease of $\mathrm{HDL}_{2}$-free cholesterol was limited to elevated ambient temperatures $(P \leq 0.01$ vs. $P>0.10$ during normal ambient tempera-

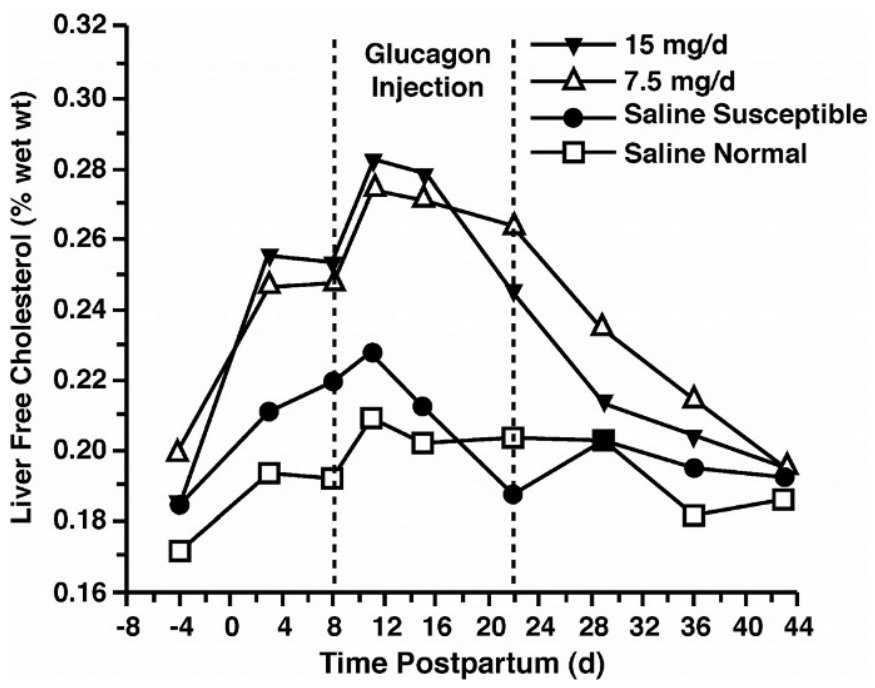

Figure 2. Effects of $7.5(P \leq 0.10)$ and $15 \mathrm{mg} / \mathrm{d}$ of glucagon $(P \leq$ 0.10 ) and of elevated liver triacylglycerol concentrations (Susceptible; $P \leq 0.05$ ) on concentrations of liver free cholesterol (SEM $=0.05$ to $0.43 ; \mathrm{n}=8$ in each treatment group).

tures; Figure 8). Injections of $7.5 \mathrm{mg} / \mathrm{d}$ of glucagon decreased concentrations of $\mathrm{HDL}_{1}-\mathrm{TAG}(P \leq 0.05$; results not shown).

Glucagon injections increased concentrations of LDLfree cholesterol more than did saline injections at normal ambient temperatures $(P \leq 0.01)$ but not at elevated ambient temperatures $(P>0.10$; Figure 9$)$. Glucagon tended to increase concentrations of $\mathrm{HDL}_{1}$-protein more at normal ambient temperatures and increased concen-

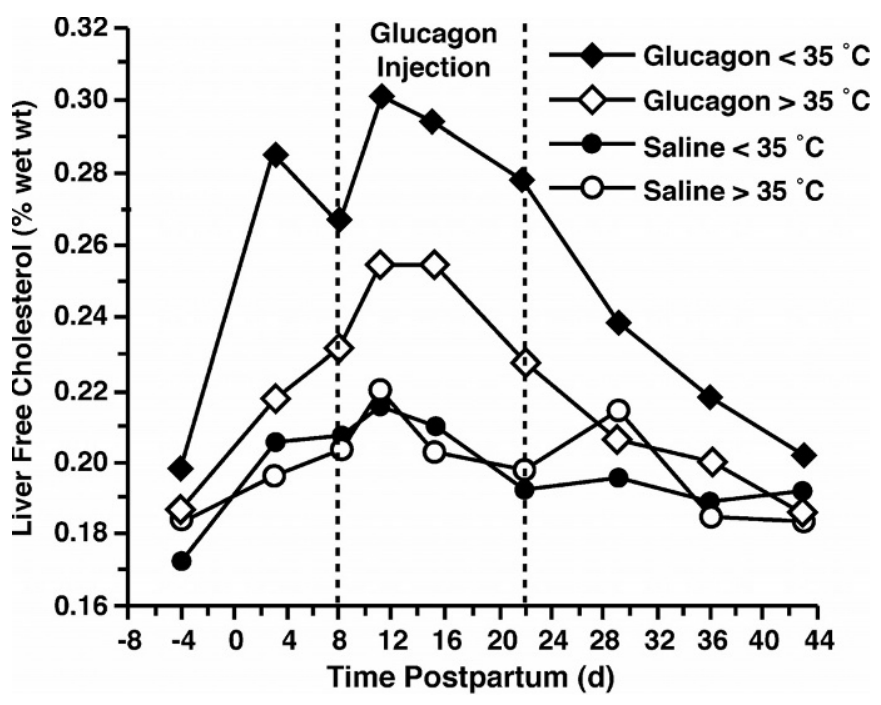

Figure 3. Effects of glucagon at $<35(P \leq 0.01)$ and $>35^{\circ} \mathrm{C}$ ambient temperature (NS) and of glucagon by ambient temperature interaction $(P \leq 0.05)$ on concentrations of liver free cholesterol $(\mathrm{SEM}=0.04$ to $0.44 ; \mathrm{n}=7$ to 9 in each group). 


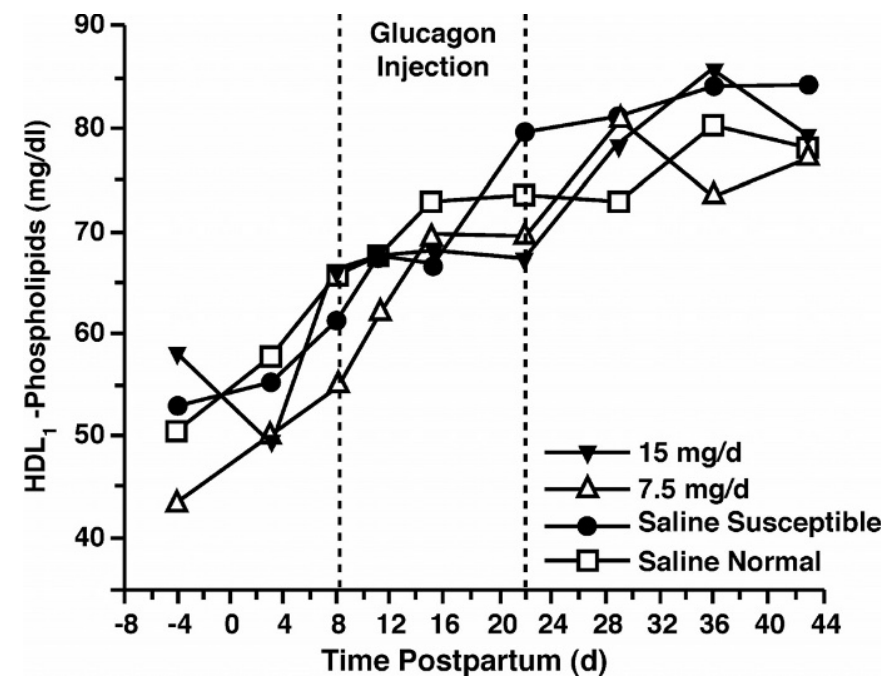

Figure 4. Effects of $7.5(P \leq 0.10)$ and $15 \mathrm{mg} / \mathrm{d}$ of glucagon $(P \leq$ 0.01 ) and of elevated liver triacylglycerol concentrations (Susceptible; $P \leq 0.10)$ on concentrations of plasma $\mathrm{HDL}_{1}$-phospholipids $(\mathrm{SEM}=$ 2.0 to $11.7 ; \mathrm{n}=8$ in each treatment group).

trations less at elevated ambient temperatures $(P \leq$ 0.05 ; Figure 10). Injections of $15 \mathrm{mg} / \mathrm{d}$ of glucagon decreased concentrations of $\mathrm{HDL}_{1}$-protein in "susceptible" cows younger than $3.5 \mathrm{yr}(P \leq 0.05)$ but not in cows older than $3.5 \mathrm{yr}(P>0.10$; Figure 11). Injections of 15 $\mathrm{mg} / \mathrm{d}$ of glucagon tended to increase concentrations of $\mathrm{HDL}_{2}$-cholesteryl esters in older cows but not in younger cows (Figure 12). Injections of $15 \mathrm{mg} / \mathrm{d}$ of glucagon tended to increase concentrations of LDL-cholest-

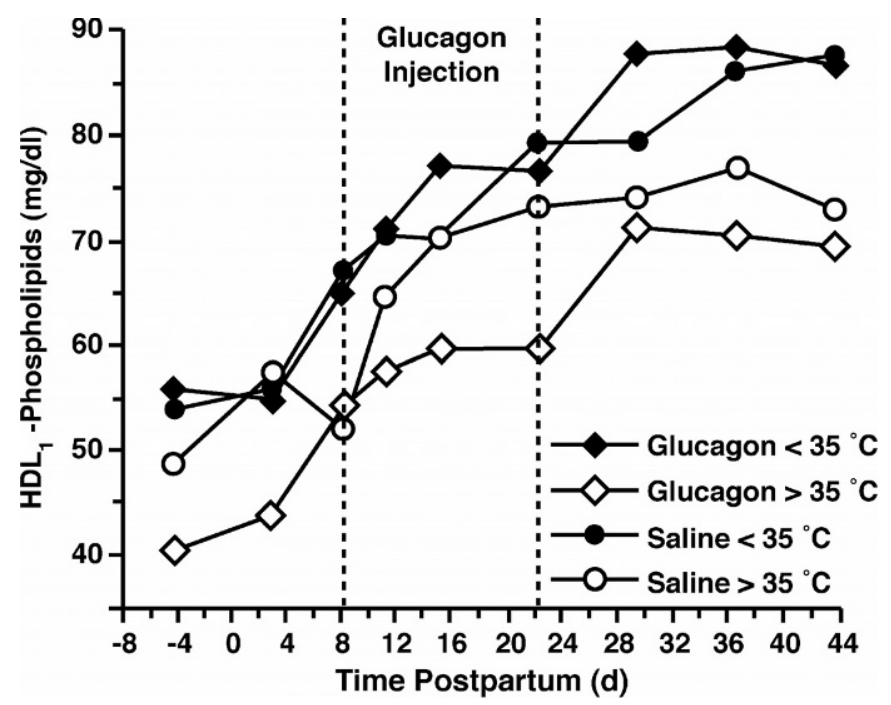

Figure 5. Effects of glucagon at $<35$ (NS) and $>35^{\circ} \mathrm{C}$ ambient temperature $(P \leq 0.10)$ and of glucagon by ambient temperature interaction $(P \leq 0.10)$ on concentrations of plasma $\mathrm{HDL}_{1}$-phospholipids (SEM $=1.8$ to $11.6 ; \mathrm{n}=7$ to 9 in each group).

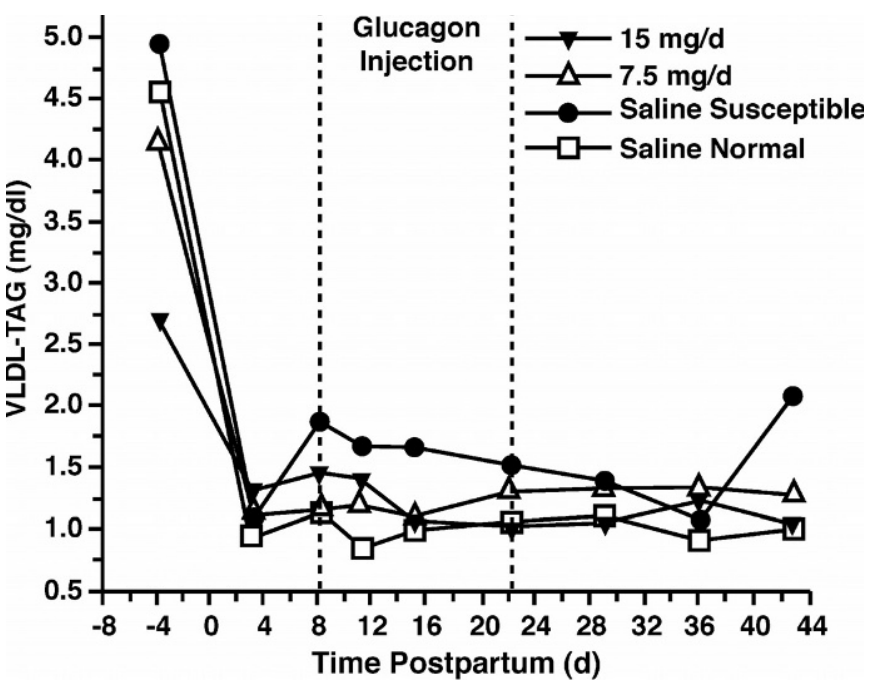

Figure 6. Effects of $7.5(\mathrm{NS})$ and $15 \mathrm{mg} / \mathrm{d}$ of glucagon $(P \leq 0.10)$ and of elevated liver triacylglycerol concentrations (Susceptible; NS) on concentrations of plasma VLDL-TAG (SEM $=0.08$ to $1.69 ; \mathrm{n}=8$ in each treatment group).

eryl ester more than did saline, and the increase was more pronounced at normal ambient temperatures $(P$ $\leq 0.001$ vs. $P>0.10$ at elevated ambient temperatures; data not shown).

Cows with elevated concentrations of liver TAG had higher concentrations of liver-free cholesterol (Figure 2 ), tended to have higher concentrations of LDL-free cholesterol and -phospholipids (results not shown), and tended to have lower concentrations of $\mathrm{HDL}_{1}$-phospho-

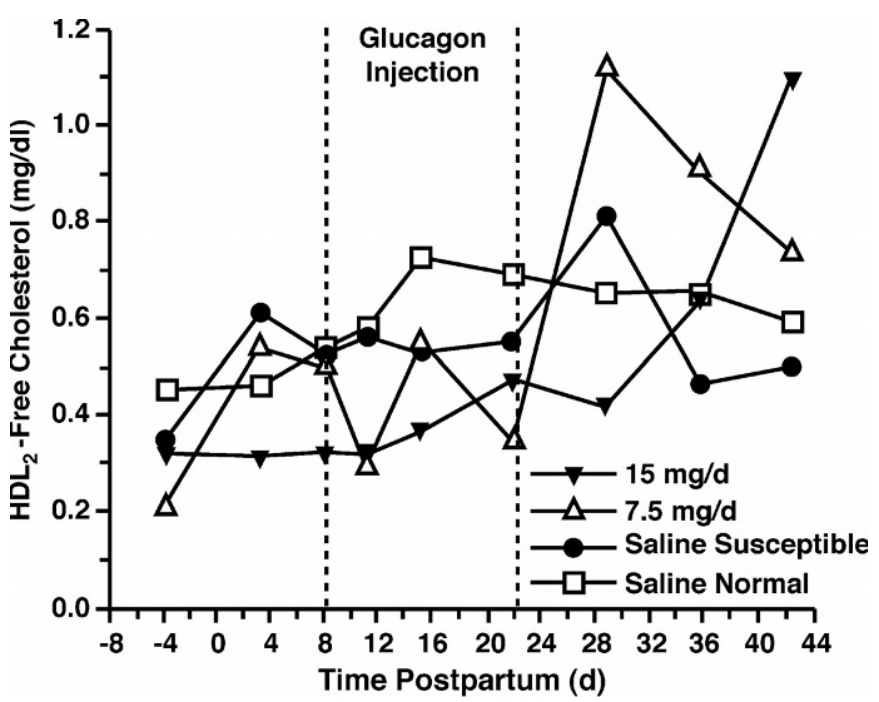

Figure 7. Effects of $7.5(P \leq 0.10)$ and $15 \mathrm{mg} / \mathrm{d}$ of glucagon (NS) and of elevated liver triacylglycerol concentrations (Susceptible; NS) on concentrations of plasma $\mathrm{HDL}_{2}$-free cholesterol (SEM $=0.07$ to $0.36 ; \mathrm{n}=8$ in each treatment group). 


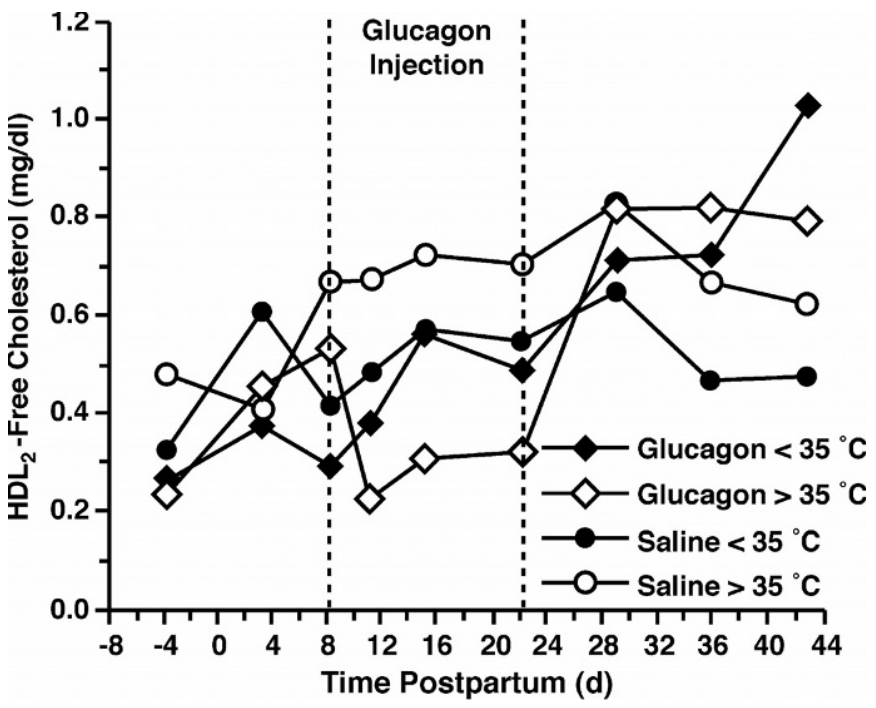

Figure 8. Effects of glucagon at $<35$ (NS) and $>35^{\circ} \mathrm{C}$ ambient temperature $(P \leq 0.01)$ and of glucagon by ambient temperature interaction $(P \leq 0.10)$ on concentrations of plasma $\mathrm{HDL}_{2}$-free cholesterol ( $\mathrm{SEM}=0.05$ to $0.38 ; \mathrm{n}=7$ to 9 in each group).

lipids at d 8 postpartum (Figure 4 ). The effect of glucagon and elevated liver TAG on concentrations of liver cholesteryl ester, LDL-TAG, -phospholipids, and -protein, $\mathrm{HDL}_{1}$-free cholesterol and -cholesteryl ester, and $\mathrm{HDL}_{2}$-phospholipids and -proteins were not significant and are not shown.

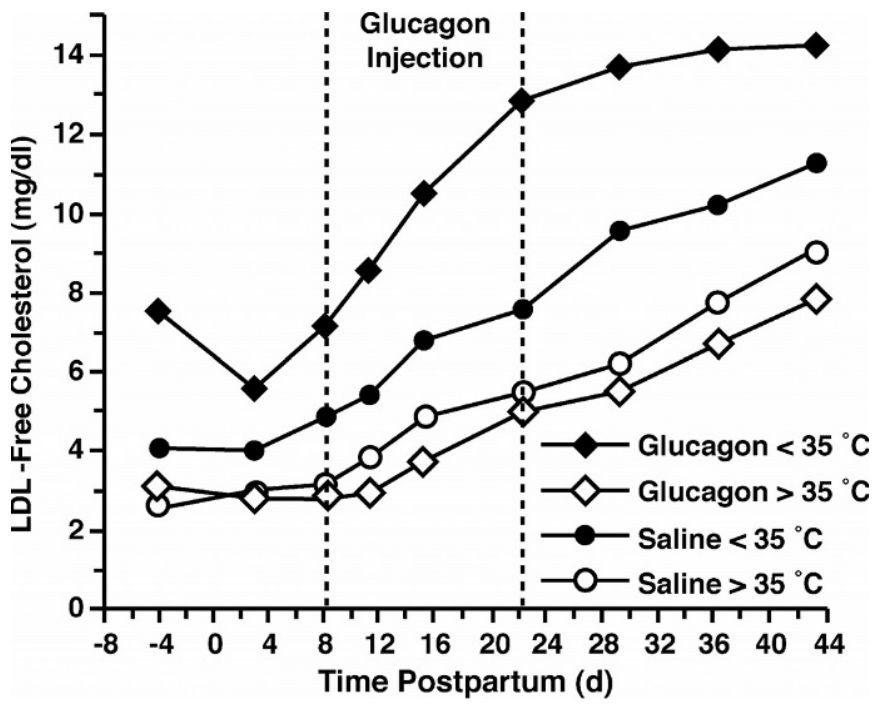

Figure 9. Effects of glucagon at $<35(P \leq 0.01)$ and $>35^{\circ} \mathrm{C}$ ambient temperature (NS) and of glucagon by ambient temperature interaction $(P \leq 0.05)$ on concentrations of plasma LDL-free cholesterol (SEM $=0.31$ to $1.76 ; \mathrm{n}=7$ to 9 in each group).

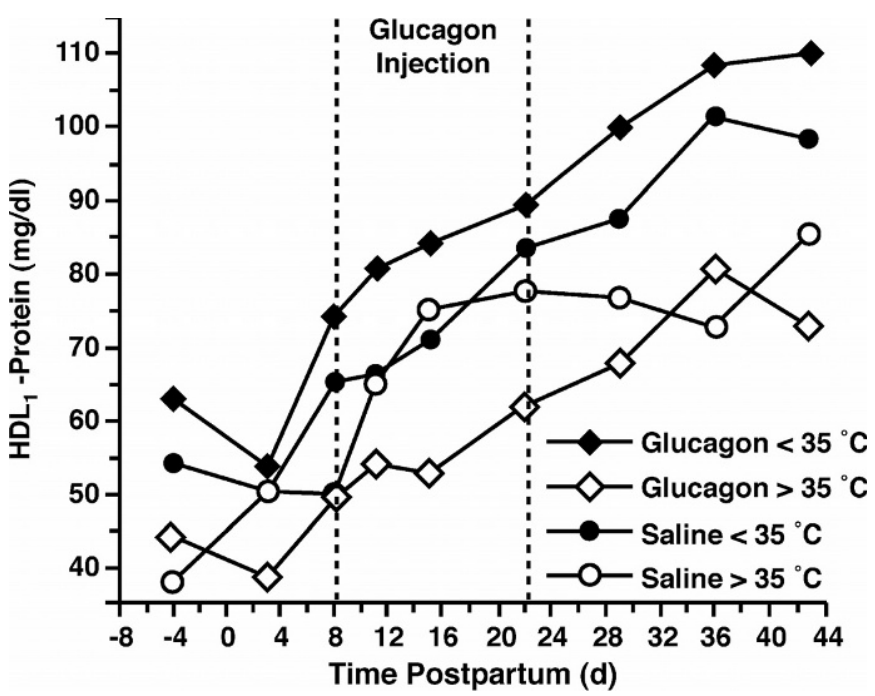

Figure 10. Effects of glucagon at $<35(P \leq 0.10)$ and $>35^{\circ} \mathrm{C}$ ambient temperature $(P \leq 0.05)$ and of glucagon by ambient temperature interaction $(P \leq 0.01)$ on concentrations of plasma $\mathrm{HDL}_{1}$-protein $(\mathrm{SEM}$ $=2.8$ to $10.9 ; \mathrm{n}=7$ to 9 in each group).

\section{DISCUSSION}

The objective of the current study was to determine whether subcutaneous injections of 7.5 and $15 \mathrm{mg} / \mathrm{d}$ of glucagon for $14 \mathrm{~d}$ starting at d 8 postpartum affect concentrations of plasma lipoprotein components and liver phospholipids, free cholesterol, and cholesteryl esters in cows with fatty liver. The concentrations of liver lipids (Figures 1 to 3 ) were similar to literature values

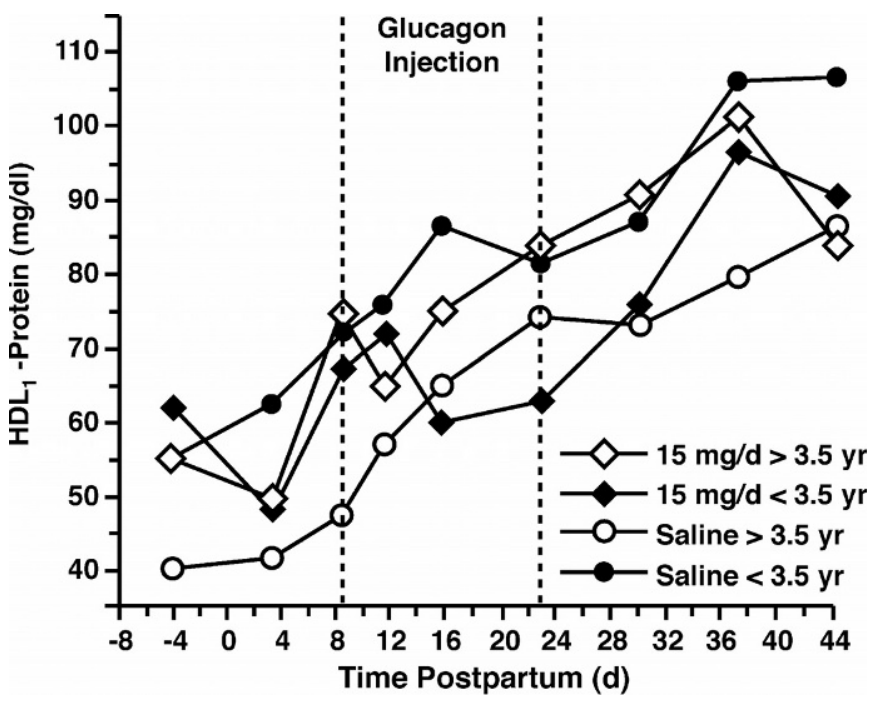

Figure 11. Effects of $15 \mathrm{mg} / \mathrm{d}$ of glucagon in cows $>3.5$ (NS) and $<3.5 \mathrm{yr}(P \leq 0.05)$ and of $15 \mathrm{mg} / \mathrm{d}$ of glucagon by age of cow interaction $(P \leq 0.05)$ on concentrations of plasma $\mathrm{HDL}_{1}$-protein $(\mathrm{SEM}=0.25$ to $22.81 ; \mathrm{n}=4$ in each group). 


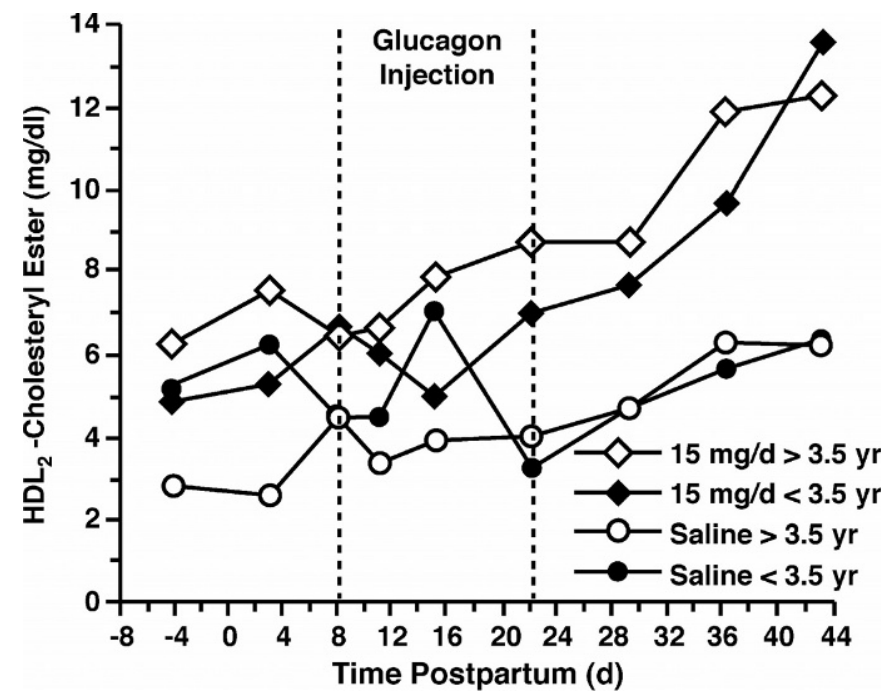

Figure 12. Effects of $15 \mathrm{mg} / \mathrm{d}$ of glucagon in cows $>3.5(P \leq 0.10)$ and $<3.5 \mathrm{yr}(\mathrm{NS})$ and of $15 \mathrm{mg} / \mathrm{d}$ of glucagon by age of cow interaction $(P \leq 0.10)$ on concentrations of plasma $\mathrm{HDL}_{2}$-cholesteryl ester (SEM $=0.4$ to $2.6 ; \mathrm{n}=4$ in each group).

(Saarinen and Shaw, 1950; Fronk et al., 1980; Herdt et al., 1983). The concentrations of lipoprotein TAG, phospholipids, free cholesterol, cholesteryl esters, and total protein in plasma (Figures 4 to 12 ) and the composition of lipoproteins were within the reference ranges of results previously reported (Herdt et al., 1983; Rayssiguier et al., 1988; Mazur et al., 1989; Bauchart, 1993; Bobowiec et al., 1997; Nakagawa et al., 1997).

The results demonstrate that subcutaneous injections of glucagon affect concentrations of some, but not all, plasma lipoprotein components and liver lipids of dairy cows in early lactation. In comparison to saline, injections of glucagon either increased or tended to increase concentrations of liver phospholipids (Figure 1) and free cholesterol (Figure 2) and either decreased or tended to decrease concentrations of VLDL-TAG (Figure 6), $\mathrm{HDL}_{1}$-phospholipids (Figure 4), and $\mathrm{HDL}_{2}$-free cholesterol (Figure 7). The differences between glucagon- and saline-injected cows tended toward statistical significance, but differences were barely evident from the raw numbers, as shown in Figures 1, 2, 4, 6, and 7. Such small changes strongly suggest that the effect of glucagon in dairy cows in early lactation are probably minor and of limited physiological significance.

A major concern was that glucagon would decrease concentrations of plasma lipoprotein components in lactating dairy cows by 20 to $50 \%$, as is the case for monogastric species (Guettet et al., 1989, 1991; Björnsson et al., 1992). Such a decrease could have detrimental effects on health and performance of lactating dairy cows. Glucagon either decreased or tended to decrease con- centrations of VLDL-TAG (Figure 6), $\mathrm{HDL}_{1}$-phospholipids (Figure 4), and $\mathrm{HDL}_{2}$-free cholesterol (Figure 7). However, none of the decreases was close to being 20 to $50 \%$ and, therefore, not likely to be detrimental to health and performance of dairy cows. Furthermore, decreased concentrations of $\mathrm{HDL}_{1}$-phospholipids (Figure 4) and $\mathrm{HDL}_{2}$-free cholesterol (Figure 7) were limited to prolonged periods of elevated ambient temperatures (Figures 5 and 8). Another indication of minimal or no detrimental effects on health and performance is that neither milk production, health status, nor reproductive performance was decreased in cows that were injected with glucagon (Bobe, 2002; Bobe et al., 2003).

From the results of this experiment, it is suspected that glucagon has beneficial effects on composition of plasma lipoproteins and liver lipids. Cows injected with glucagon either increased or tended to increase concentrations of liver phospholipids and free cholesterol (Figures 1 and 2). Subcutaneous injections of $15 \mathrm{mg} / \mathrm{d}$ of glucagon decreased concentrations of liver TAG (Bobe et al., 2003) and tended to increase concentrations of $\mathrm{HDL}_{2}$-cholesteryl ester in cows older than $3.5 \mathrm{yr}$ (Figure 12). Furthermore, glucagon increased concentrations of LDL-free cholesterol (Figure 9) and tended to increase concentrations of $\mathrm{HDL}_{1}$-protein (Figure 10) during periods when ambient temperatures were constantly below $35^{\circ} \mathrm{C}$. The probable reason why glucagon increased rather than decreased concentrations of liver lipids other than TAG and plasma lipoprotein components is that injections of glucagon over several days increase concentrations of plasma glucose and insulin, which in turn increase both synthesis and secretion of liver lipids and lipoproteins (Pullinger and Gibbons, 1985). It can be hypothesized that the effects of glucagon on liver lipids and lipoprotein components and on liver glycogen are similar. Concentrations of liver glycogen are decreased during the first few days of glucagon treatment, but then they increase because concentrations of plasma glucose and insulin are increased (Hippen et al., 1999). A beneficial, indirect effect of glucagon on liver lipid and plasma lipoprotein concentrations by decreasing concentrations of liver TAG cannot be excluded.

Glucagon injections resulted in greater increases in concentrations of liver lipids other than TAG and smaller decreases in plasma lipoprotein components in cows older than $3.5 \mathrm{yr}$ and during ambient temperatures below $35^{\circ} \mathrm{C}$. Glucagon at $15 \mathrm{mg} / \mathrm{d}$ tended to increase concentrations of $\mathrm{HDL}_{2}$ cholesteryl ester in cows older than $3.5 \mathrm{yr}$ but not in cows younger than 3.5 $\mathrm{yr}$ (Figure 12) and decreased concentrations of $\mathrm{HDL}_{1}$ protein only in cows younger than $3.5 \mathrm{yr}$ (Figure 11). Glucagon increased concentrations of liver and LDLfree cholesterol (Figures 3 and 9) and tended to increase 
concentrations of $\mathrm{HDL}_{1}$-protein (Figure 10) during ambient temperatures below $35^{\circ} \mathrm{C}$ but not during prolonged periods when ambient temperatures were above $35^{\circ} \mathrm{C}$. Only during a prolonged period of ambient temperatures above $35^{\circ} \mathrm{C}$ did glucagon decrease concentrations of $\mathrm{HDL}_{2}$-free cholesterol (Figure 8) and $\mathrm{HDL}_{1}$ protein (Figure 10) and tend to decrease concentrations of $\mathrm{HDL}_{1}$-phospholipids (Figure 5).

The greater increases and smaller decreases of concentrations of plasma lipoprotein components and liver phospholipids, free cholesterol, and cholesteryl esters might be associated with the smaller energy deficits of older cows and during ambient temperatures below $35^{\circ} \mathrm{C}$. Because they are still growing, cows younger than $3.5 \mathrm{yr}$ probably have greater energy requirements than do older cows. Ambient temperatures above $35^{\circ} \mathrm{C}$ decrease feed intake and, therefore, increase the energy deficit of cows in early lactation (Skaar et al., 1989; Itoh et al., 1998). Glucagon administered during an increased energy deficit in monogastric species has been demonstrated to be more catabolically associated with increased hepatic uptake and catabolism of lipoproteins (Brown et al., 1989; Guettet et al., 1988, 1991). Increasing the availability of gluconeogenic substrates by oral or dietary administration might spare the use of proteins as gluconeogenic substrates for the action of glucagon and thereby increase concentrations of liver lipids other than TAG and plasma lipoprotein components during glucagon administration.

\section{CONCLUSIONS}

Subcutaneous injections of 7.5 and $15 \mathrm{mg} / \mathrm{d}$ of glucagon for $14 \mathrm{~d}$ beginning at $\mathrm{d} 8$ postpartum have only minor effects on concentrations of either lipoprotein components in plasma or liver phospholipids, free cholesterol, and cholesteryl esters of dairy cows in early lactation. Such changes probably are not of major physiological significance. In contrast to monogastric species, injections of glucagon did not cause large decreases of 20 to $50 \%$ in concentrations of lipoprotein components in plasma and liver phospholipids, free cholesterol, and cholesteryl ester. Instead, glucagon 1) increased concentrations of liver phospholipids overall, 2) increased concentrations of liver free cholesterol and LDL-free cholesterol and tended to increase concentrations of $\mathrm{HDL}_{1}$-protein during normal ambient temperatures below $35^{\circ} \mathrm{C}$ and 3 ) tended to increase concentrations of $\mathrm{HDL}_{2}$-cholesteryl esters in cows older than $3.5 \mathrm{yr}$. Those changes suggest that increasing the availability of gluconeogenic substrates by oral or dietary administration might improve the beneficial effects of glucagon on concentrations of liver lipids and plasma lipoproteins. Most importantly, the results provide no indications that glu- cagon would have effects on the concentrations of lipoprotein components in plasma or liver lipids that would be detrimental in any way to lactating dairy cows. The possibility of utilizing glucagon as an effective preventative or treatment for fatty liver in early-lactating dairy cows, therefore, continues to be a viable option that warrants further investigation.

\section{ACKNOWLEDGMENTS}

The authors thank Eli Lilly (Indianapolis, IN) for donation of glucagon. The research was partly supported by grant number 99-35005-8576 from the US Department of Agriculture and was part of regional research project NC-185. Appreciation is extended to the management of the Iowa State University Dairy Teaching Herd for provision of cows, to K. J. Koehler for assistance in statistical analyses, and to Y. Lu, R. A. Nafikov, R. Sonon, and many undergraduate and veterinary medical students for assistance in collecting and analyzing liver and blood samples.

\section{REFERENCES}

Bauchart, D. 1993. Lipids absorption and transport in ruminants. J. Dairy Sci. 76:3864-3881.

Björnsson, O. G., J. M. Duerden, S. M. Bartlett, J. D. Sparks, C. E. Sparks, and G. F. Gibbons. 1992. The role of pancreatic hormones in the regulation of lipid storage, oxidation and secretion in primary cultures of rat hepatocytes. Short- and long-term effects. Biochem. J. 281:381-386.

Bobe, G. 2002. Metabolic responses of lactating dairy cows to exogenous glucagon. Ph.D. Diss., Iowa State University, Ames.

Bobe, G., B. N. Ametaj, D. C. Beitz, and J. W. Young. 2003. Potential treatment of fatty liver with 14-day subcutaneous injections of glucagon. J. Dairy Sci. (accepted).

Bobowiec, R., J. Filar, J. Marczuk, and U. Kosior. 1997. Periparturient changes in plasma lipoprotein composition of dairy cows. Medycyna Wet. 53:734-738.

Brown, N. F., A. M. Salter, R. Fears, and D. N. Brindley. 1989 Glucagon, cyclic AMP and adrenaline stimulate the degradation of low-density lipoprotein by cultured rat hepatocytes. Biochem. J. 262:425-429.

Douglass, L. W. 2002. Analysis of correlated measures: Temporally related observations, repeated measures analysis. Pages 10-15 in NCR-170 FASS Mixed Model Workshop. Quebec City, QC, Canada.

Fronk, T. J., L. H. Schultz, and A. R. Hardie. 1980. Effect of dry period overconditioning on subsequent metabolic disorders and performance of dairy cows. J. Dairy Sci. 63:1080-1090.

Graulet, B., D. Gruffat, D. Durand, and D. Bauchart. 1998. Fatty acid metabolism and very low density lipoprotein secretion in liver slices from rats and ruminant calves. J. Biochem. (Tokyo) 124:1212-1219.

Grum, D. E., J. K. Drackley, R. S. Younker, D. W. LaCount, and J. J. Veenhuizen. 1996. Nutrition during the dry period and hepatic lipid metabolism of periparturient dairy cows. J. Dairy Sci. 79:1850-1864.

Guettet, C., D. Mathé, N. Navarro, and B. Lecuyer. 1989. Effects of chronic glucagon administration on rat lipoprotein composition. Biochim. Biophys. Acta 1005:233-238.

Guettet, C., N. Rostaqui, D. Mathé, B. Lecuyer, N. Navarro, and B. Jacotot. 1991. Effect of chronic glucagon administration on lipoprotein composition in normally fed, fasted and cholesterolfed rats. Lipids 26:451-458. 
Havel, R. J., H. A. Eder, and J. H. Bragdon. 1955. The distribution and chemical composition of ultracentrifugally separated lipoproteins in human serum. J. Clin. Invest. 34:1345-1353.

Herdt, T. H. 1991. Relationship of fat metabolism to health and performance in dairy cattle. Bov. Pract. 26:92-95.

Herdt, T. H., J. Liesman, B. Gerloff, and R. Emery. 1983. Reduction of serum triacylglycerol-rich lipoprotein concentrations in cows with hepatic lipidosis. Am. J. Vet. Res. 44:293-296.

Hippen, A. R., P. She, J. W. Young, D. C. Beitz, G. L. Lindberg, L. F. Richardson, and R. W. Tucker. 1999. Alleviation of fatty liver in dairy cows with 14-day intravenous infusions of glucagon. J. Dairy Sci. 82:1139-1152.

Itoh, F., Y. Obara, M. T. Rose, H. Fuse, and H. Hashimoto. 1998. Insulin and glucagon secretion in lactating cows during heat exposure. J. Anim. Sci. 76:2182-2189.

Jorritsma, R., H. Jorritsma, Y. H. Schukken, P. C. Bartlett, T. Wensing, and G. H. Wentink. 2001. Prevalence and indicators of post partum fatty infiltration of the liver in nine commercial dairy herds in The Netherlands. Livest. Prod. Sci. 68:53-60.

Katoh, N. 2002. Relevance of apolipoproteins in the development of fatty liver and fatty liver-related peripartum diseases in dairy cows. J. Vet. Med. Sci. 64:293-307.

Mazur, A., E. Marcos, and Y. Rayssiguier. 1989. Plasma lipoproteins in dairy cows with naturally occurring severe fatty liver: Evidence of alteration in the distribution of apo A-I-containing lipoproteins. Lipids 24:805-811.

McGarry, J. D., and D. W. Foster. 1980. Effects of exogenous fatty acid concentration on glucagon-induced changes in hepatic fatty acid metabolism. Diabetes 29:236-240.

Nakagawa, H., S. Oikawa, T. Oohashi, and N. Katoh. 1997. Decreased serum lecithin:cholesterol acyltransferase activity in spontaneous cases of fatty liver in cows. Vet. Res. Commun. 21:1-8.

Pullinger, C. R., and G. F. Gibbons. 1985. Effects of hormones and pyruvate on the rates of secretion of very-low-density lipoprotein triacyglycerol and cholesterol by rat hepatocytes. Biochim. Biophys. Acta 833:44-51.

Rayssiguier, A., A. Mazur, E. Gueux, I. M. Reid, and C. J. Roberts. 1988. Plasma lipoproteins and fatty liver in dairy cows. Res. Vet. Sci. 45:389-393.

Reid, I. M. 1983. Reproductive performance and fatty liver in Guernsey cows. Anim. Reprod. Sci. 5:275-279.
Reid, I. M. 1984. Update on fatty liver and fertility. Dairy cow fertility. Pages 81-88 in Proc. Joint Br. Vet. Assoc. and Br. Soc. Anim. Prod. Conf., Bristol Univ., UK.

Ropstad, E., K. Halse, and A. O. Refsdal. 1989. Variations in parameters of liver function and plasma progesterone related to underfeeding and ketosis in a dairy herd. Acta Vet. Scand. 30:185-197.

Saarinen, P., and J. C. Shaw. 1950. Studies on ketosis in dairy cattle. XIII. Lipids and ascorbic acid in the liver and adrenals of cows with spontaneous and fasting ketosis. J. Dairy Sci. 33:515-525.

SAS User's Guide: Statistics, Version 8.2. 2001. SAS Inst., Inc., Cary, NC.

Skaar, T. C., R. R. Grummer, M. R. Dentine, and R. H. Stauffacher. 1989. Seasonal effects of prepartum and postpartum fat and niacin on lactation performance and lipid metabolism. J. Dairy Sci. 72:2028-2038.

Smith, T. R., A. R. Hippen, D. C. Beitz, and J. W. Young. 1997. Metabolic characteristics of induced ketosis in normal and obese dairy cows. J. Dairy Sci. 80:1569-1581.

Tempelman, R. J. 2002. Mixed models and SAS PROC MIXED: An introduction. Pages 11-16 in NCR-170 FASS Mixed Model Workshop. 2002 ADSA-ASAS-CSAS Natl. Mtg., Quebec City, QC, Canada.

van den Top, A. M., M. J. H. Geelen, T. Wensing, G. H. Wentink, A T. van't Klooster, and A. C. Beynen. 1996. Higher postpartum hepatic triacylglycerol concentrations in dairy cows with free rather than restricted access to feed during the dry period are associated with lower activities of hepatic glycerolphosphate acyltransferase. J. Nutr. 126:76-85.

Watson, E. D., and L. A. Williams. 1987. Influence of liver fat on post-partum hormone profiles in dairy cows. Anim. Prod. 45:9-14.

Wensing, T., T. Kruip, M. J. H. Geelen, G. H. Wentink, and A. M. van den Top. 1997. Postpartum fatty liver in high-producing dairy cows in practice and in animal studies. The connection with health, production and reproduction problems. Comp. Haematol. Int. 7:167-171.

Witters, L. A., and C. S. Trasko. 1979. Regulation of hepatic free fatty acid metabolism by glucagon and insulin. Am. J. Physiol. 237:E23-E29.

Zhou, J., J. Zhang, W. Tian, and C. Zheng. 1997. Study of the effect of fatty liver on fertility in periparturient cows. Acta Vet. Zootechn. Sin. 28:115-119. 